\title{
良性脳腫愓に対する神経内視鏡手術一今後の方向性一
}

\author{
渡邊 督1), 岩味 健一郎 ${ }^{1)}$, 岸田 悠吾 ${ }^{2}$, 永谷 哲也 ${ }^{2)}$ \\ 1）愛知医科大学脳神経外科，2）名古屋第二赤十字病院脳神経外科神経内視鏡センター
}

\section{Future Prospective on Minimally Invasive Endoscopic Surgery for Benign Brain Tumors}

\author{
Tadashi Watanabe, M.D. ${ }^{1)}$, Kenichiro Iwami, M.D. ${ }^{1)}$, Yugo Kishida, M.D. ${ }^{2)}$, and Tetsuya Nagatani, M.D. ${ }^{2)}$ \\ 1) Department of Neurosurgery, Aichi Medical University, 2) Center for Neuroendoscopic Surgery, Department of Neurosur- \\ gery, Nagoya Daini Red Cross Hospital
}

A wide field of view and minimal surgical trauma serve as advantages of endoscopic surgery. Endoscopic endonasal surgery and endoscopic hematoma removal are currently being performed, and the development of sophisticated equipment, novel techniques, and education/training in this field have led to improved surgical outcomes and wide acceptance of this approach in clinical practice. Neuroendoscopic cylinder surgery for intraventricular/intraparenchymal tumors and minimally invasive transcranial endoscopic surgery for extra-axial tumors are alternative endoscopic approaches used in neurosurgery. Currently, endoscopy guided dissection of nerves and blood vessels can be performed to ensure meticulous manipulation of these delicate structures.

Most benign brain tumors are extra-axial lesions. We are presently investigating an endoscopic keyhole approach that enables observation of the anatomy beyond bony protrusions and nerves through a limited access site. The introduction of high-resolution endoscopes and three-dimensional exoscopes has led to improved visualization of the endoscopic field and also provided a choice of viewpoints. The operation is performed by viewing a monitor, and the holder can be shared; therefore, procedures can be performed by appropriately switching between the endoscope and exoscope based on the demands of the operation. An endoscope facilitates multi-view surgery, and can also be used for team surgery during which different approaches, such as a transnasal and transcranial approach can be combined. Minimal invasiveness is a known advantage of endoscopic procedures; other advantages include a greater likelihood of radical cure owing to a wide viewing angle and/or multiple viewpoints to aid in better visualization of the operative field. In a rapidly aging society, it is reasonable not to expect cure but symptom relief for benign lesions. In our view, endoscopic surgery is a useful approach for procedures such as coagulation of feeding vessels and decompression surgery. The endoscopic approach is expected to play a significant role in both radical and minimally invasive surgery performed as palliative treatment.

(Received June 21, 2020 ; accepted July 3, 2020)

Key words : endoscope, keyhole, exoscope, minimum invasive, benign brain tumor

Jpn J Neurosurg (Tokyo) $29: 642-651,2020$

連絡先：渡邊 督， $=480-1195$ 長久手市岩作雁又 1-1 愛知医科大学脳神経外科

Address reprint requests to: Tadashi Watanabe, M.D., Department of Neurosurgery, Aichi Medical University, 1-1 Karimata, Yazako, Nagakute-shi, Aichi 480-1195, Japan 


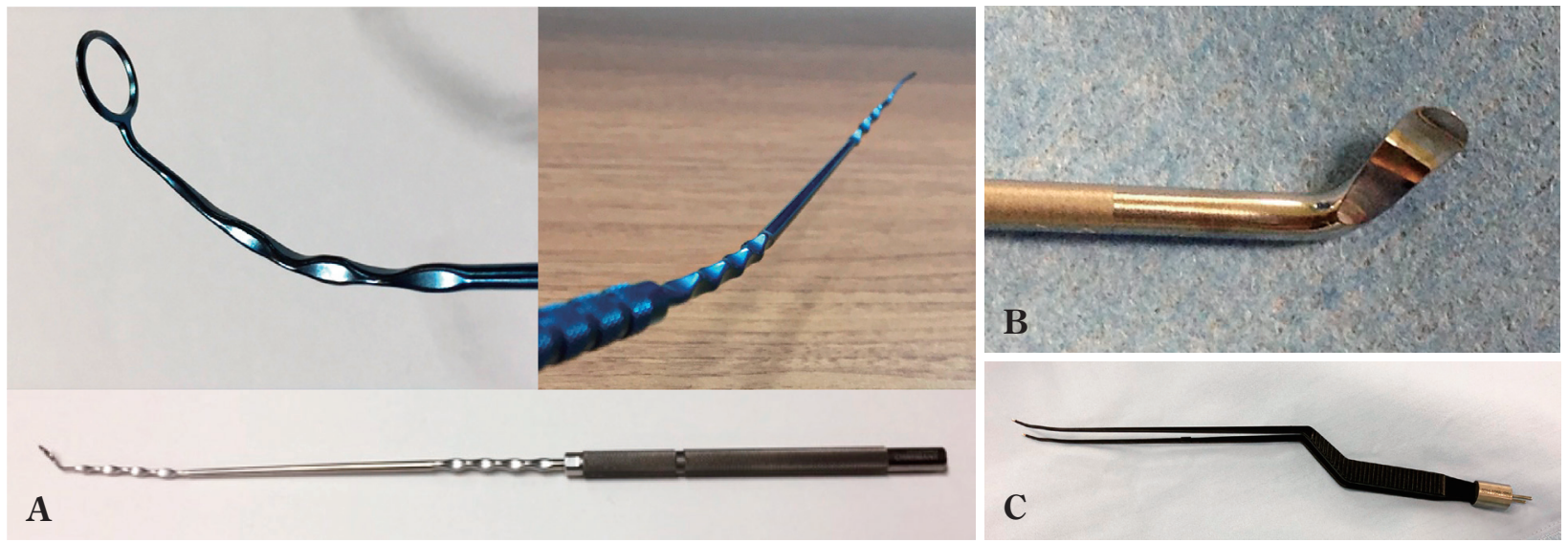

Fig. 1 A : Mizuho-Charmant malleable dissector. This instrument is designed to bend at two points, the tip and the handle.

B : Storz rotating dissector.

C : Fujita flexible bipolar coagulator.

\section{はじめに}

Schwartz $ら^{8)}$ による内視鏡下頭蓋底手術のレビュー で，序文として Charles B. Wilson の言葉が紹介されてい る。“変化に伴う興奮でしばしば忘れがちな前提条件は, 新しい技術が患者のための臨床ケアの質を向上させるこ とである。この前提条件が満たされない場合，その技術 は放棄されるべきである”。つまり，新しい技術は魅力的 でみな飛びつくが，本当の意味で患者のためになってい なければその技術は残らないであろうということであ る。われわれ内視鏡脳神経外科医はこのことを肝に銘じ て努力をし，改善していかなければならない。この論文 の中で, 内視鏡下経鼻手術においては, この 20 年間のパ ラダイムシフトの中で, 頭蓋咽頭腫, 脊索腫は経鼻手術 に分があるという結論に至っており，われわれの実感と してもまったく同意できるとともに時代の変化を感じる ことができる。経鼻手術に加えわれわれが着目している のは，小開頭による経頭蓋アプローチで，内視鏡の特徵 を駆使して何ができるかという点である.

内視鏡を使った経頭蓋アプローチは 2000 年代から報 告されるようになり ${ }^{2(2)}$ 4) , 筆者らも内視鏡を利用し低 侵襲小開頭手術を開始した。視点が術野に入り視野角が 広い特徵は, 低侵襲性と根治性という両面をもつ。本稿 では主に脳実質外腫瘍である良性腫瘍に対する内視鏡下 小開頭アプローチを中心に，これまでの経験と現状，今 後の方向性について論じる.

\section{内視鏡の特徵}

内視鏡の最大の特徵は, 広い視野角である。死角が減 ることで, 腫瘍の取り残しが減り，根治性が高まるとい える，頭蓋骨の骨構造に隠れた，顕微鏡の視点では死角 となる部分は，視野角の大きさにより，あるいは斜視鏡 の使用により観察可能となる。同時に小さな入り口から アクセスできる点も重要な特徴であり, 低侵襲性を実現 できる.

一方, 最大の課題が, 視点が中に入ることによって生 じる, 内視鏡と手術器具の干渉の問題である。この克服 のためにさまざまな工夫が必要である。第 1 には, 器具 の工夫である。内視鏡手術においては先の曲がった器 具，マレアブルなシャフトをもつ器具がしばしば重要な 役割を果たす (Fig. 1)。第 2 にはスコピストの役割であ る. 手術器具が当たらない上うに術野における内視鏡の 位置を適宜微調整することは，術中重要な局面では，手 術をスムーズに進行するために重要である。そのため, 顕微鏡手術に比べ, 動的な視点をもつ手術といえる. 第 3 には外視鏡の活用である。近年登場した外視鏡の特徵 は，視点が顕微鏡と同様術野の外にあり，顕微鏡に比心゙ 鏡体が小さい点と, 内視鏡と同じくモニターを見ながら 行う手術であり，内視鏡手術への移行がスムーズである 点である．外視鏡で進められる操作を行い，深部が見に くい，死角が気になるようになってきた時点で内視鏡に 変える. 最後に, 器具の干渉が引き起こす不用意な動き を避けるには，力を抜いて手術を行うことも重要である と考えている。つまり, 内視鏡手術において器具が動か ない瞬間はしばしばあり，このようなときに無理に動か 

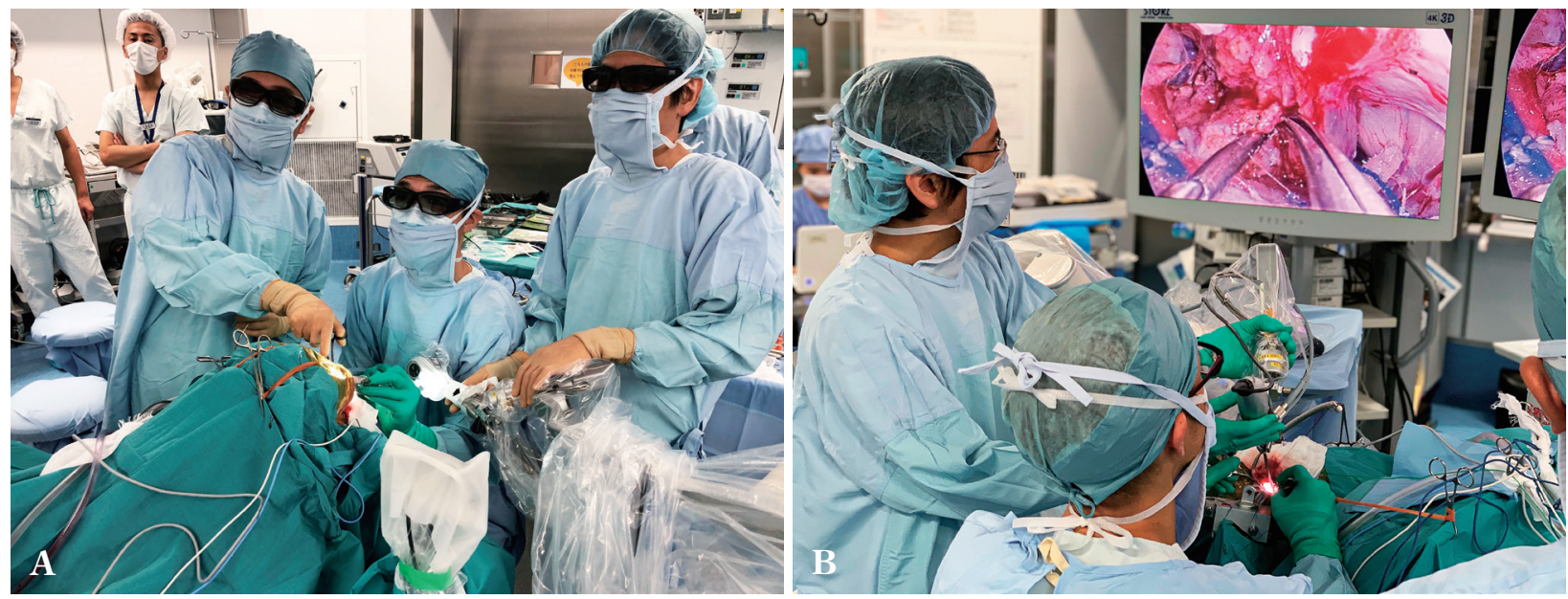

Fig. 2 A : The assistant (endoscopist) is controlling the 3D VITOM (Storz) system. The visual axis is nearly horizontal, and the surgeon views the monitor in a comfortable position.

B : Lateral occipital approach is performed with the endoscope in a supine-lateral position.

3D : three-dimensional

そうとすると, 不用意な動きが生じ, 危険が生じる可能 性がある.

もう 1 つの課題が, 術野より浅い部分の視野が死角に なる点である。これはときに重大な合併症につながるの で注意が必要である。器具の挿入の際は, スコピストが 内視鏡を動かして誘導する, あるいは肉眼で術野の器具 がライトで照らされるまで確認し, その後モニターに目 を移すなどの工夫が必要である。現状ではやや煩雑では あるが, 外視鏡と内視鏡を同一術野で使用し, 浅い術野, 深部の術野を同時に観察しながら手術をする方法もあ $ろ^{5)}$. 重要な神経や血管の向こう側の操作は, 器具の シャフトによる損傷に注意する必要があるので, やはり 限定的な動きになる。

\section{方 法}

われわれは 2007 年から内視鏡下小開頭アプローチに 取り組み始め, 当初は前頭蓋底の髄膜腫, 開頭が必要な 下垂体腺腫などを, 眉毛切開の小開頭で, 眼窩上アプ ローチを中心に行っており, その後, 側頭下アプローチ, 外側後頭下アプローチなどバリエーションが広がつ た ${ }^{11)}$. 硬膜切開までは直視下に行い, その後内視鏡観察 下に操作を行った。内視鏡の確実な固定が必要であり, ホルダーはオリンパスエンドアーム, もしくは三鷹ユニ アームを使用した。現在内視鏡は $4 \mathrm{~K}$ カメラ (Storz IMAGE1）を，外視鏡は Storz VITOM 3D を使用してい る.アプローチおよび摘出, 剝離操作の一部は外視鏡で 行い, 深部, 死角の観察, 操作を内視鏡で行う。精密な
観察を行うには少なくとも high definitionの解像度は必 要であると考えている.内視鏡，外視鏡はともに視軸の 自由度が高い特徴があり，水平方向や見上げる向きの視 軸でも操作が可能である。術者はより楽な姿勢をとるこ とができ, 患者の体位の自由度も高く, 特に外側後頭下 アプローチにおいては仰側臥位で肩を挙上し頭部を 90 度回転する姿位ですべての操作が可能である。（Fig. 2B)

眼窩上アプローチに拈ける眉毛切開については, 皮膚 切開が短い利点はあるが，顔面に傷を加えることに抵抗 がある患者も存在するため, 患者に情報提供のうえよく 相談をして決めるようにしている。眼窩上アプローチ, 外側後頭下開頭，側頭下開頭などにおいては， $5 \sim 6 \mathrm{~cm}$ の皮膚切開に $2.5 \sim 3 \mathrm{~cm}$ の開頭を加える. 開頭術野に内 視鏡を置くスペースが必要であり, 長径 $2.5 \mathrm{~cm}$ 以下の大 きさになると, 操作性が落ちる。また, $5 \mathrm{~cm}$ を超える開 頭になると, 開頭縁での内視鏡の固定がしづらくなり, かえって不安定となる。 そのため, 適切な大きさの開頭 が重要である。前頭側頭開頭, 大脳鎌病変は腫瘍の状態 により必要に応じて長径 $2.5 \sim 5 \mathrm{~cm}$ の開頭で行った。 眼 窩上アプローチでは開頭縁の内板や, 眼窩上壁の骨隆起 が操作に影響するので，これらを削り，快適な術野を作 る細やかな配慮が必要である。

器具の出し入れによる脳表の損傷を避けるために, 綿 片で脳表を保護する。術野画面に道具を挿入するため に, 前述のように, 直視下に器具がライトに当たるまで 確認するか, 助手が内視鏡を動かして, 追随するなどの 工夫が必要である $($ Fig. 2, 3)。内視鏡は $2 \mathrm{D}$ であるため に, くも膜などの薄い組織を切る際の操作性は $3 \mathrm{D}$ 観察 


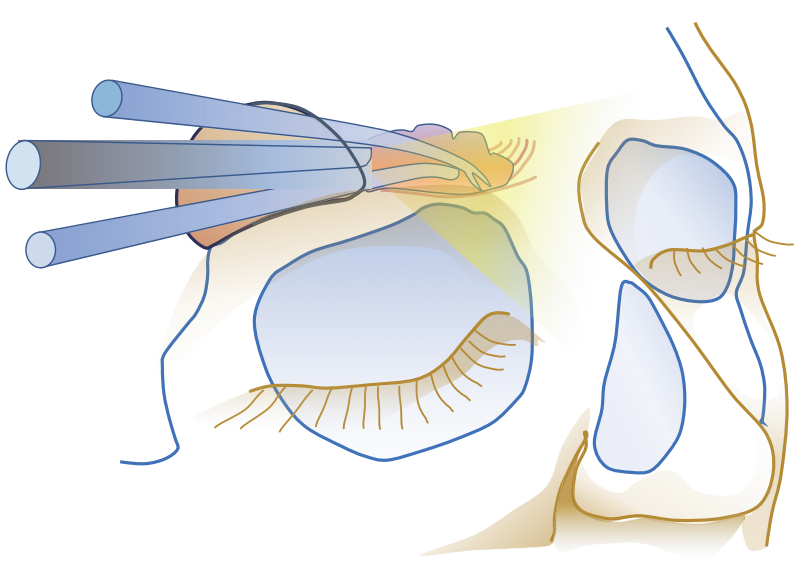

Fig. 3 Schema showing the endoscopic supraorbital keyhole approach

下に比べやや劣る。はさみやメスによる鋭的な切開操作 も器具の動きが少し遅くなる傾向がある。腫瘍の剝離操 作など多くの操作では $2 \mathrm{D}$ であっても問題なくできる.

内視鏡手術のもう 1 つの特徴として, 人工髄液灌流下 の術野（wet-field technique）での操作が可能な点があ る。これは脳室内手術, 脳内手術，脳内血腫除去術など ではしばしば使用するテクニックであるが，脳実質外腫 瘍に対するこのアプローチにおいても, 髄液中の生理的 環境下での観察, 摘出後の神経, 血管の状態確認, 止血. 確認などで wet-field technique はしばしば使用する。特 に神経血管減圧術のような無血術野においては，神経保 護の観点に加え, 光の反射が抑えられた非常にクリアな 画像が得られるので有用である (Fig. 4).

\section{最近のスタイル}

外視鏡を取り入れてからは，術者の好みにもよるが， 腫瘍へのアプローチ，あるいは腫瘍の剝離，摘出を外視 鏡で可能な範囲で行う。小開頭でのアプローチであるの で死角の観察の必要性は高く後半は内視鏡で作業を行 う。当施設では外視鏡はStorz VITOM 3D を使用してい るので，内視鏡手術と同様，助手がホルダーに装着した 鏡体を常に動かしコントロールを行い，また，ハンドコ ントローラーで倍率，焦点を合わせる（Fig. 2A）。

\section{内視鏡手術に必要な手術器具}

内視鏡下の操作においては，術野で見えない部分での 器具の干渉があり, 対象物が見えるものの器具が動かな い場面にしばしば遭遇する。その解決法の 1 つとして,

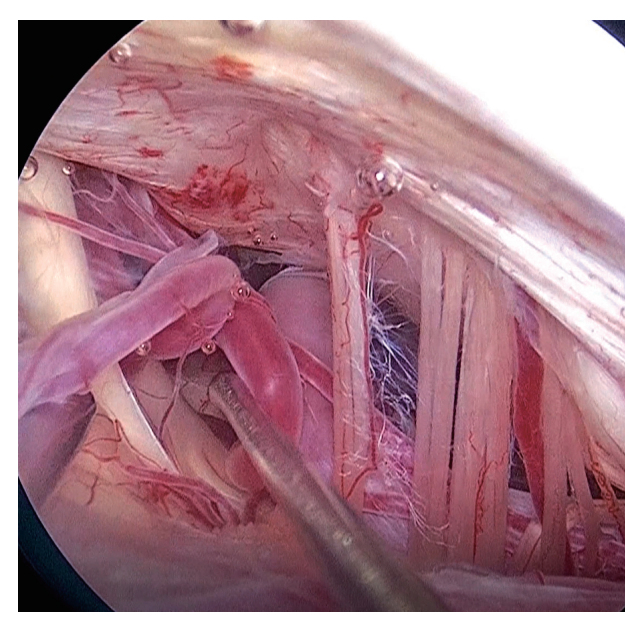

Fig. 4 Endoscopic view of microvascular decompression performed in a wet operating field in a patient with right hemifacial spasm

The anatomical relationship between the facial nerve and a loop of the posterior inferior cerebellar artery is clearly visualized.

シャフトの曲がった器具，あるいはマレアブルな器具を 使用する，形状を整えることで目的の操作を，内視鏡や ほかの構造と干渉しないようにする（Fig. 1)。また，剝 離子の軸を回転させる運動で，先端を動かすことができ る器具も有用である。回転運動によりシャフトは動かな いため，内視鏡や，構造物の干涉はほぼ影響しない。操 作の慣れが重要であるとともに, 内視鏡手術のための器 具を揃えることも重要である。最近では経鼻内視鏡手術 の発展に伴い, 神経内視鏡手術用の器具のバリエーショ ンも増えてきている.

\section{経験症例}

脳実質外病変に対し内視鏡・外視鏡下小開頭手術を 行った症例はこれまで 132 例であり, 髄膜腫 41 例, 微小 血管減圧術 28 例，神経鞘腫 17 例，下垂体腺腫（小開頭 のみ) 9 例，腺腫以外のトルコ鞍病変 6 例，乞の他 12 例 (類上皮腫, 脊索腫など), 経鼻開頭同時手術 19 例（下垂 体腺腫，頭蓋咽頭腫など）であった。すべての症例で予 定どおりの腫瘍摘出を行うことができた。髄膜腫におい ては，嗅窩，中頭蓋底前方，視神経管内側など，術野外 からの視点では観察困難な部位は，内視鏡観察下の操作 が有用であった。また内視鏡を使用することにより㚘骨 弓を外す手技を省略することができた（Fig. 5)。静脈洞 交会に付着部をもつ髄膜腫においては，後頭下開頭から 

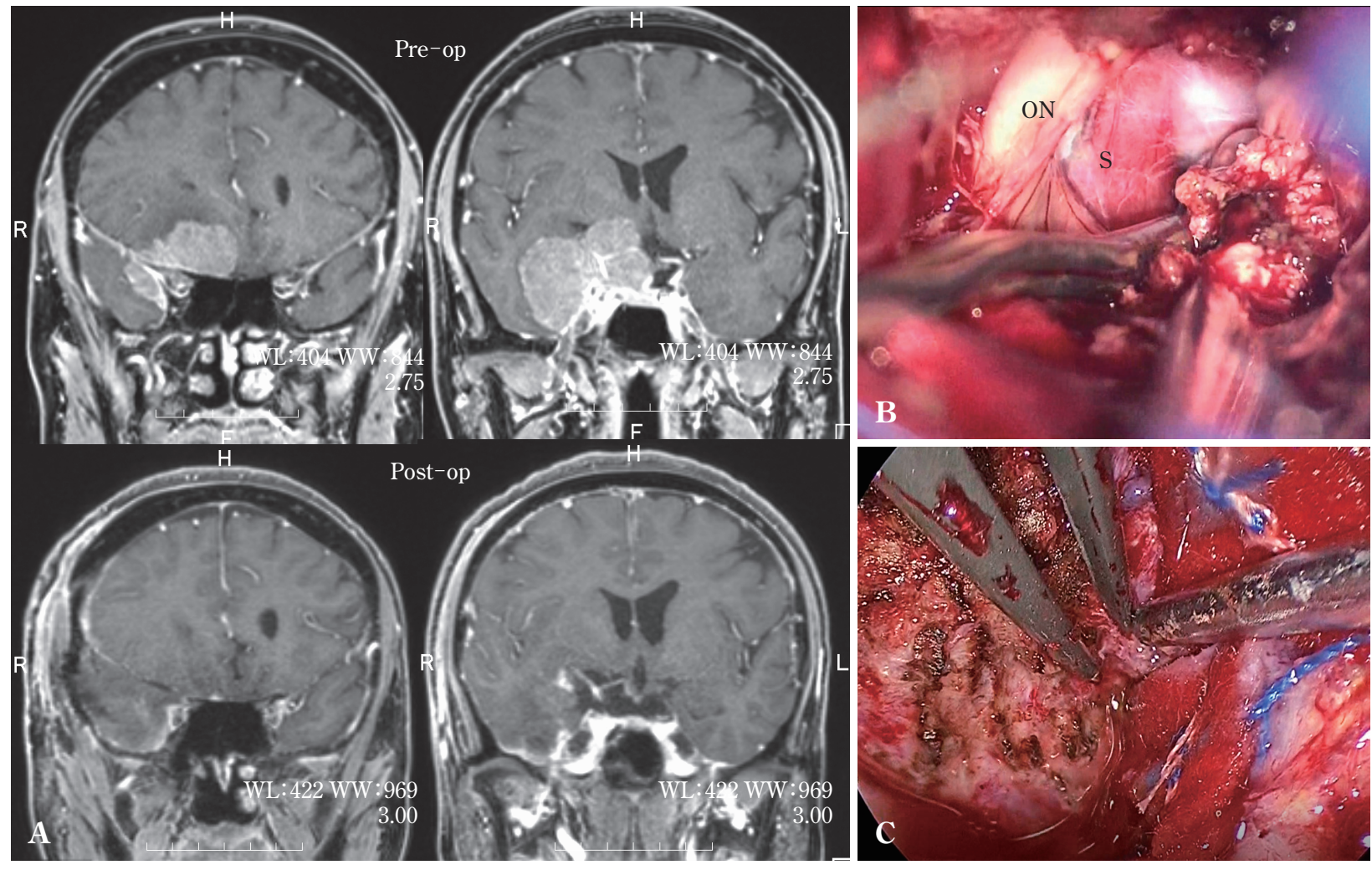

Fig. 5 Representative case of a 59-year-old woman with a diagnosis of clinoid meningioma

Exoscopic and endoscopic tumor removal was performed via a frontotemporal craniotomy $(4 \mathrm{~cm})$ using a partial anterior clinoidectomy technique without cutting the zygomatic arch. After gross resection of the tumor using an exoscope, the remnant tumor around the optic canal and middle fossa was removed under endoscopic guidance.

A : Pre- $^{-}$and postoperative contrast-enhanced MRI scans (coronal view).

B : Exoscopic view showing compression of the right $\mathrm{ON}$ medially and the stalk after tumor removal.

C : Endoscopic view showing removal of the residual tumor of the anterolateral middle fossa.

MRI : magnetic resonance imaging, ON : optic nerve

の観察は内視鏡が有用であった $(\text { Fig. 6 })^{1)}$. 微小血管減圧 術においては責任血管の走行が広範囲に観察可能であ り，良好な観察下の操作が得られた（Fig. 4)。聴神経鞘 腫においては内耳道内の腫瘍の処理が内視鏡下に可能で あった，前方，側方に突出する巨大な下垂体腺腫におい ては経鼻手術と内視鏡下眼窩上アプローチの合同手術に て, 双方からの摘出, 観察, 安全確認ができ, 有効な共 同作業ができた (Fig. 7). 多発の大脳鎌髄膜腫において は主病変の摘出ののち, 内視鏡下に複数の病変を摘出可 能であった ${ }^{12)}$.

一方でさまざまな合併症も経験した，頭蓋咽頭腫術後 視機能悪化の 1 例, テント䯣膜腫小脳梗塞の 1 例は, 腫 瘍周囲の強い癒着, 手術操作の問題であり, アプローチ の問題ではなく, 腫瘍の性質に起因する合併症と考元ら れた。眼窩上アプローチでは感染 1 例, 内視鏡シャフト の長時間圧迫による火傷を 1 例経験した（Fig. 8)。感染 の 1 例は中年男性で骨弁除去を行ったが，その後整容面
で大きな問題はなく，形成手術を行わずに経過をみてい る. 経鼻開頭同時手術において，2 例の慢性硬膜下血腫 と肺塞栓症 1 例を経験したがいずれも適切な処置がなさ れ, 経過良好である. 慢性硬膜下血腫に対しては最近で はくも膜形成を極力行うなどの対策をとるようにしてい るが, 今後の課題である。重篤な合併症の 1 例として, テント下小脳上アプローチにて小脳出血性脳梗塞を経験 した。これは浅い術野における架橋静脈の損傷に起因 し, 内視鏡で深部を観察中に, 浅い術野が死角になる点 が問題となった。このアプローチを行う際注意すべき点 である.

髄膜腫の症例のうち, 5 症例の高齢者髄膜腫において, 腫瘍減圧手術のみを行い, 脳の露出, 髄液の流出を極力 避けて手術を行った。年齢は 79〜85 歳（中央值 83 歳） で, 79 歳の症例は軽度の認知症が術前確認された症例で あった（Fig. 9).いずれも進行する症状があり, 極力低 侵襲な手術を希望されたため, 腫瘍内減圧術を選択し 


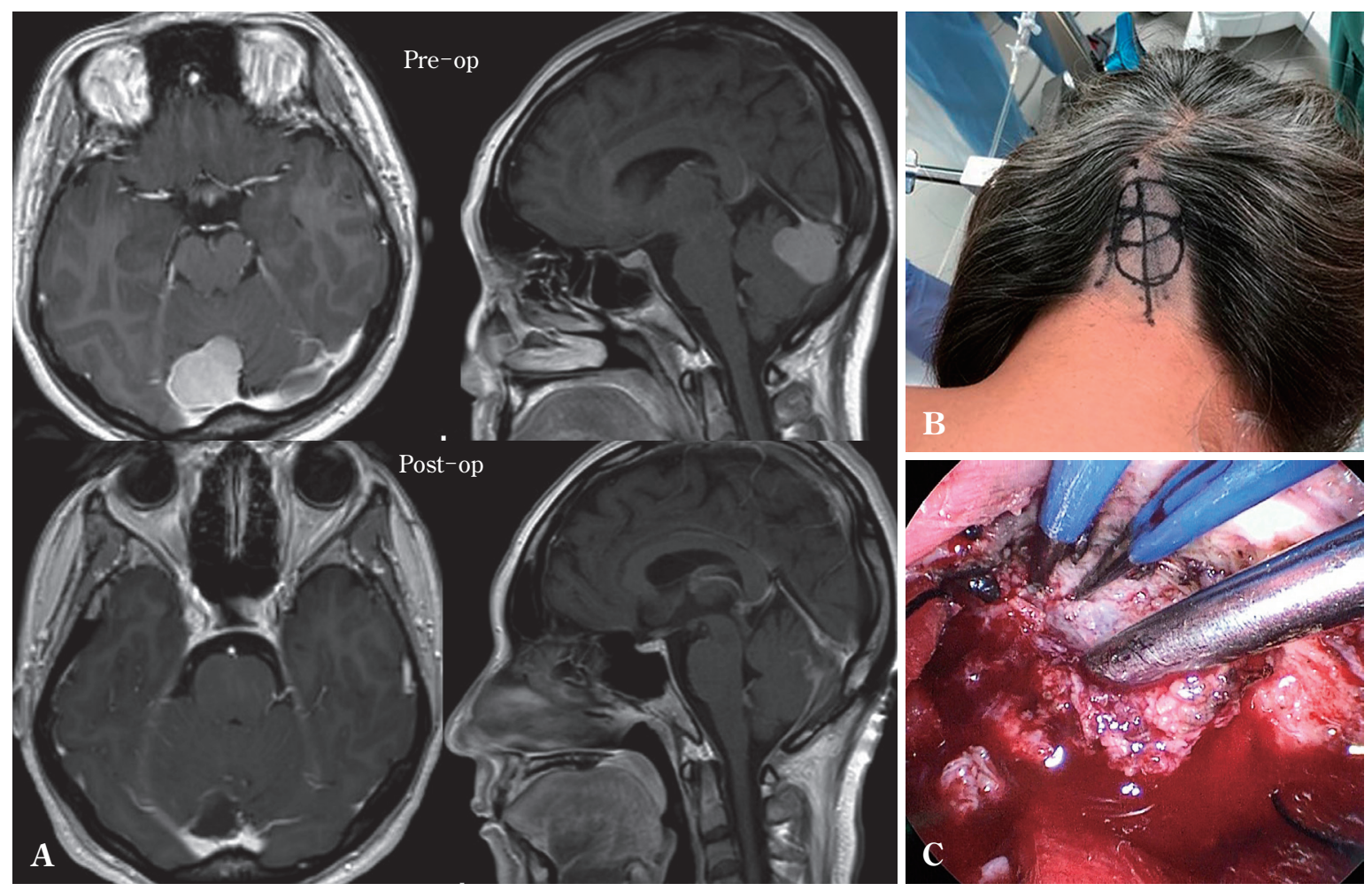

Fig. 6 Representative case of torcular meningioma

A : Pre $^{-}$and postoperative contrast ${ }^{-}$enhanced MRI scans (axial and sagittal views).

B : Photograph of a patient with the head in the fixed prone position. A craniotomy $(3 \mathrm{~cm})$ is visualized on the right side below the confluence.

$\mathrm{C}:$ Endoscopic view of the area beneath the confluence of venous sinuses.

MRI : magnetic resonance imaging

た。開頭部分は腫瘍直上に設定し，そのまま腫瘍内減圧 を行い，脳を露出しない方法をとった，小さな入り口か ら, あらゆる方向への広い視野角を利用して, 十分な減 圧が可能であった。術後全例で症状の改善が得られ, 術 翌日に離床, 経口摄取が可能となり, 術後早期の体力回 復は良好であった。術後 CTでは, 頭蓋内へのエアの混 入はない,もしくは最小限であった。

\section{考察一なぜ内視鏡が有用なのか一}

外科手術は患者の体に傷をつけて初めて始まる施術で あり,この外傷を加える行為は必要最小限にとどめるべ きであることは議論の余地はないであろう。脳神経外科 においては開頭範囲を小さくすることで, 頭皮や筋層へ の負担が減るとともに, 脳の牽引も自動的に制限される と考えられる。顕微鏡による低侵襲小開頭手術が提唱さ れたが, やはり, 間口が狭いと, 死角が生じる点, 深部 では光が届きにくくなる点が問題となる，内視鏡では頭 蓋底の骨構造や, 神経の裏, 血管の裏の観察が可能であ
り。入り口の大きさにかかわらず広大な視野で観察でき る。この最大の利点は代えがたいものであり，内視鏡を 利用した開頭術の確立を目指す大きな理由である.

またもう1つの利点として, 患者体位の自由度が高く, 術者の姿勢が楽である点がある。内視鏡，および外視鏡 の手術は, 上から見下ろすのみでなく, 水平方向の視軸, 見上げる方向の視軸などが可能であり, 視軸の自由度が 高い，そのため, 患者体位も比較的自由度が高く, 特に 外側後頭下アプローチでは仰側臥位で手術が可能であ る。また，モニターを見て行う手術であり，術者は楽な 姿勢で手術を行うことができる。

\section{根治性を高めるための内視鏡手術}

髄膜腫においては，付着部の処理が根治性に関わる。 テント下面から静脈洞交会に付着部をもつ髄膜腫は顕微 鏡による観察が困難である場合が多く，内視鏡が有用で ある．静脈洞との境界面は，損傷により大きな合併症に つながるため, 詳細な観察が必要であり, 斜視鏡が非常 

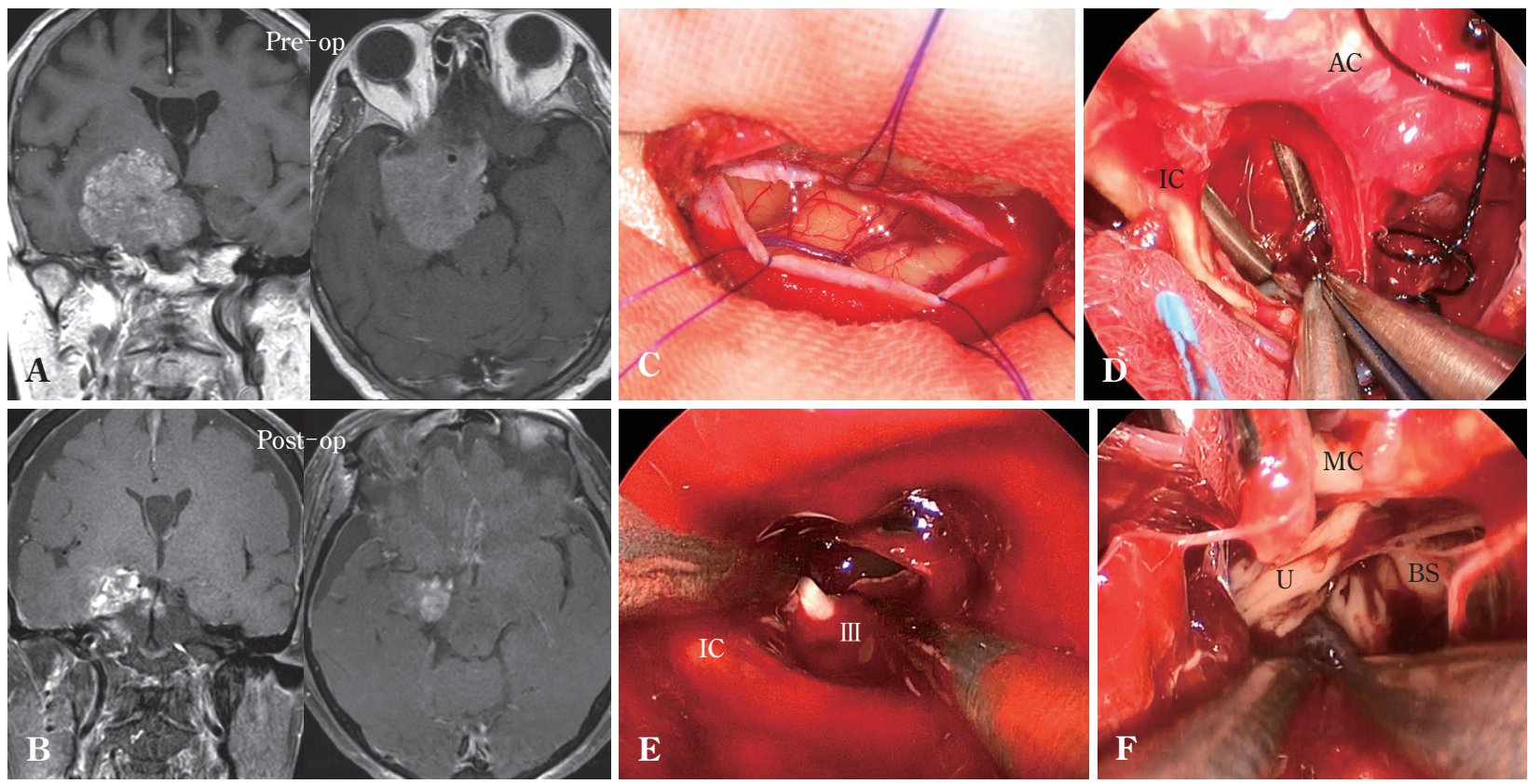

Fig. 7 Image showing a combined right supraorbital keyhole approach and endonasal approach for removal of a giant pituitary adenoma extending in the posterolateral direction. Tumor debulking performed via two corridors achieved gross total tumor resection. We traced the course of the oculomotor nerve by visualization of the nerve through two corridors.

A : Preoperative contrast-enhanced MRI scan (coronal and axial views).

B : Postoperative contrast-enhanced MRI scan (coronal and axial views).

C, D : Supraorbital keyhole craniotomy, dural incision (C), and endoscopic view showing instruments inserted via two corridors (D).

E : Endoscopic view showing the endonasal approach. The oculomotor nerve (cranial nerve III) is exposed after removing the tumor medial to the right ICA.

F : The left $U$ and BS are exposed after removing the tumor beneath the right MCA.

AC : anterior clinoid process, BS : brain stem, ICA : internal carotid artery, MCA : middle cerebral artery, MRI :

magnetic resonance imaging, $\mathrm{U}:$ uncus

に有用である. 蝶形骨縁，中頭蓋底の髄膜腫においても， 顕微鏡では観察が困難な部位があり，付着部全体に及ぶ 切除，凝固処理には内視鏡の観察が有用であった。これ までの頭蓋底外科の考え方では，骨構造を削り，脳に対 して低侵襲な手術を行う方法であったが，内視鏡の視野 角を利用することで, 骨削除も省略し侵襲を減らすこと ができる可能性があると考えている。 また，大脳鎌髄膜 腫においては大脳鎌に沿って, 内視鏡で観察し, 主病変 に加え，多発病変を処理することができる.

聴神経鞘腫においては，内視鏡，もしくは外視鏡にて 腫瘍摘出後, 内耳道内を観察する。内耳道後壁の削除を 行ったうえで斜視鏡を使用して，可及的に内耳道内腫瘍 を摘出する。脳幹側の癒着が強く剝離しない戦略の場合 は，腫崵内減圧を最大限行うために内視鏡が有用であっ た。

脳幹に複雑に入り込んだ再発類上皮腫においては，脳 幹に付着した腫瘍被膜を極力摘出する際に，斜視鏡によ
る観察と, 軸の回転運動を利用した剝離子による摘出が 有効であった ${ }^{10)}$.

微小血管減圧術においては神経根部と脳幹, 責任血管 の走行をほぼすべて観察が可能であった。さらに無血術 野においては wet-field techniqueにより光の反射やレン ズの污れのない, クリアな観察ができる. 生理的環境下 での手術の継続が可能で, 乾燥や熱損傷のリスクを軽減 することができる。また, 髄液が満たされた状態での術 後の血管，神経の位置も確認できる。

\section{高齢者における内視鏡下低侵襲手術}

高齢者の髄膜腫手術の成績は若年に比べ不良であ $り^{7)}$, 特に 80 歳を超えるような超高齢者において, 髄膜 腫のような良性腫瘍では，症状を緩和する目的の低侵襲 手術が選択されてもよいのではないかと考えており，少 しずつ症例を重礼ている。つまり，良性腫瘍の内減圧に 

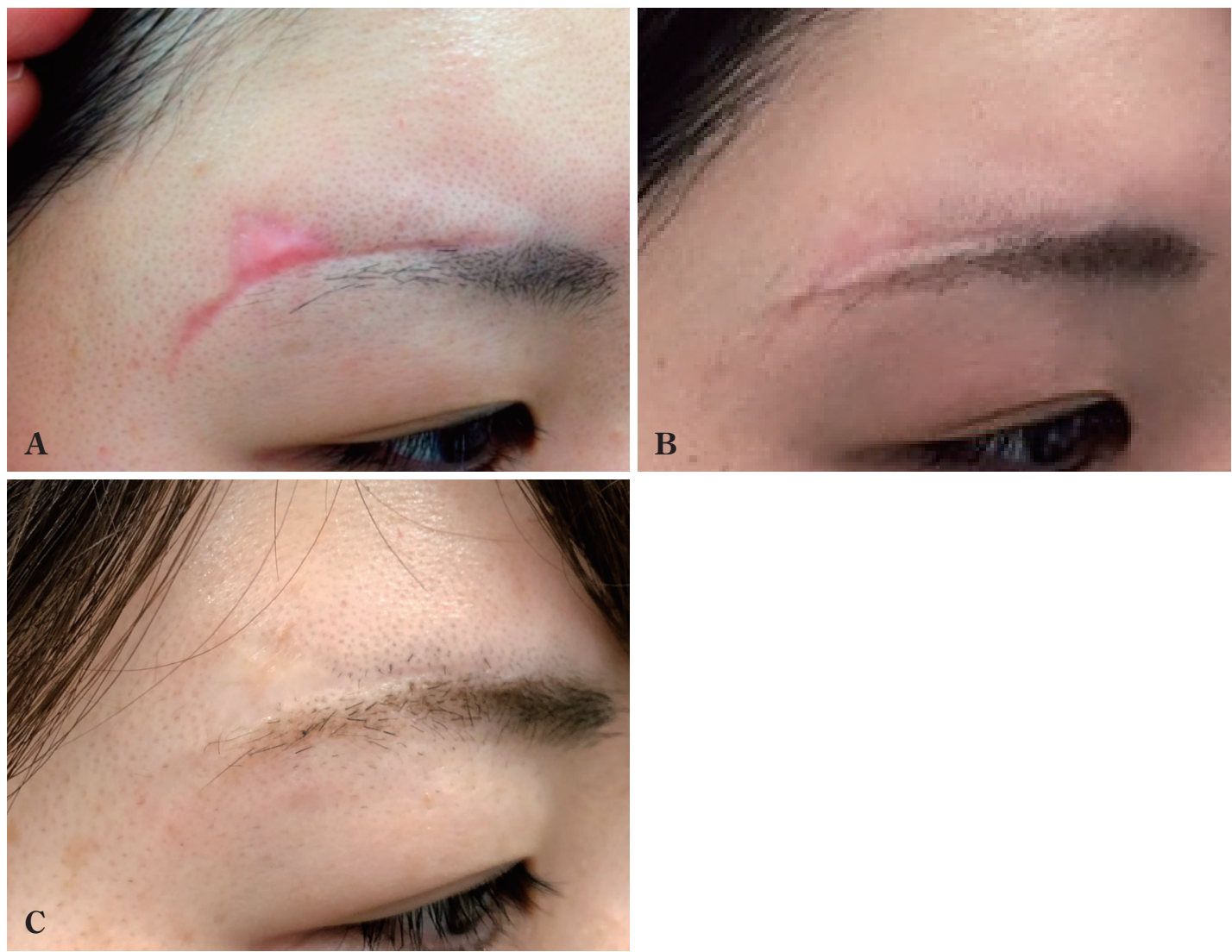

Fig. 8 Image showing a skin burn caused by the shaft of the endoscope, 2 weeks $(\mathbf{A}), 4$ months $($ B $)$, and 5 years (C) postoperatively.

よる症状緩和を目指し, 脳を露出しない, 髄液を漏出さ せない手術である。特に硬膜側から栄養を受ける髄膜腫 には，脳を露出しないまま腫瘍付着部から腫瘍内部の減 圧を行うとともに，腫瘍の栄養血管を断つことは良性腫 瘍の治療としては合理的である。髄膜腫は脳との癒着が 強いと全摘出による一過性の症状を呈することがあり高 齢ゆえにリハビリテーション効果が限定的である可能性

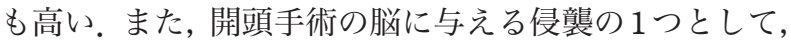
髄液の排出による影響も脳萎縮の進んだ高齢者には大き な問題である. 急性, 慢性硬膜下血腫の形成のリスクや, 術後の回復に影響があり，入院が長くなることによりそ の後の ADLに影響を及ぼす可能性がある。このような手 術において，腫瘍内で最大限の減圧を行う場面で内視鏡 は有用であると考えている。本格的な高齢化社会を迎え た本邦において今後注目される方法である.

\section{多視点手術}

複雑な進展をする腫瘍において，1つの術野のみでは 安全に腫瘍摘出を行うことが困難な症例があり, 特に巨
大下垂体腺腫においては残存腫瘍からの出血の問題があ り，2 期的手術を躊躇することも少なくない。このよう な症例には経鼻開頭同時手術が 1 つの解決策となる，異 なった視軸からの観察で，腫瘍摘出のみならず，安全確 認をまったく別の視点から得られる利点は大きい。この 際，経鼻手術に加え開頭手術も内視鏡で行うことによ り，小さな鏡体であるため術野はシンプルになり，術者 同士がモニターを確認しあうことで，より高度なコミュ ニケーションをとることができる ${ }^{6)}$ ままた，同一術野に おいても，浅い術野と深部の術野を安全確認しながら手 術操作を行う多視点手術に取り組んでいる ${ }^{5)}$ 。現状では 2 つの内視鏡システムを用意する必要があり，やや煩雑 になる。

\section{課題と今後の方向性}

内視鏡手術における大きな課題は前述したように，器 具の干渉により動きが制限されることがある点である. 引き続き，より実用的で安全な手術器具の進歩が必要で ある。また，スコピストが鏡体を動かす方法をとるため， 

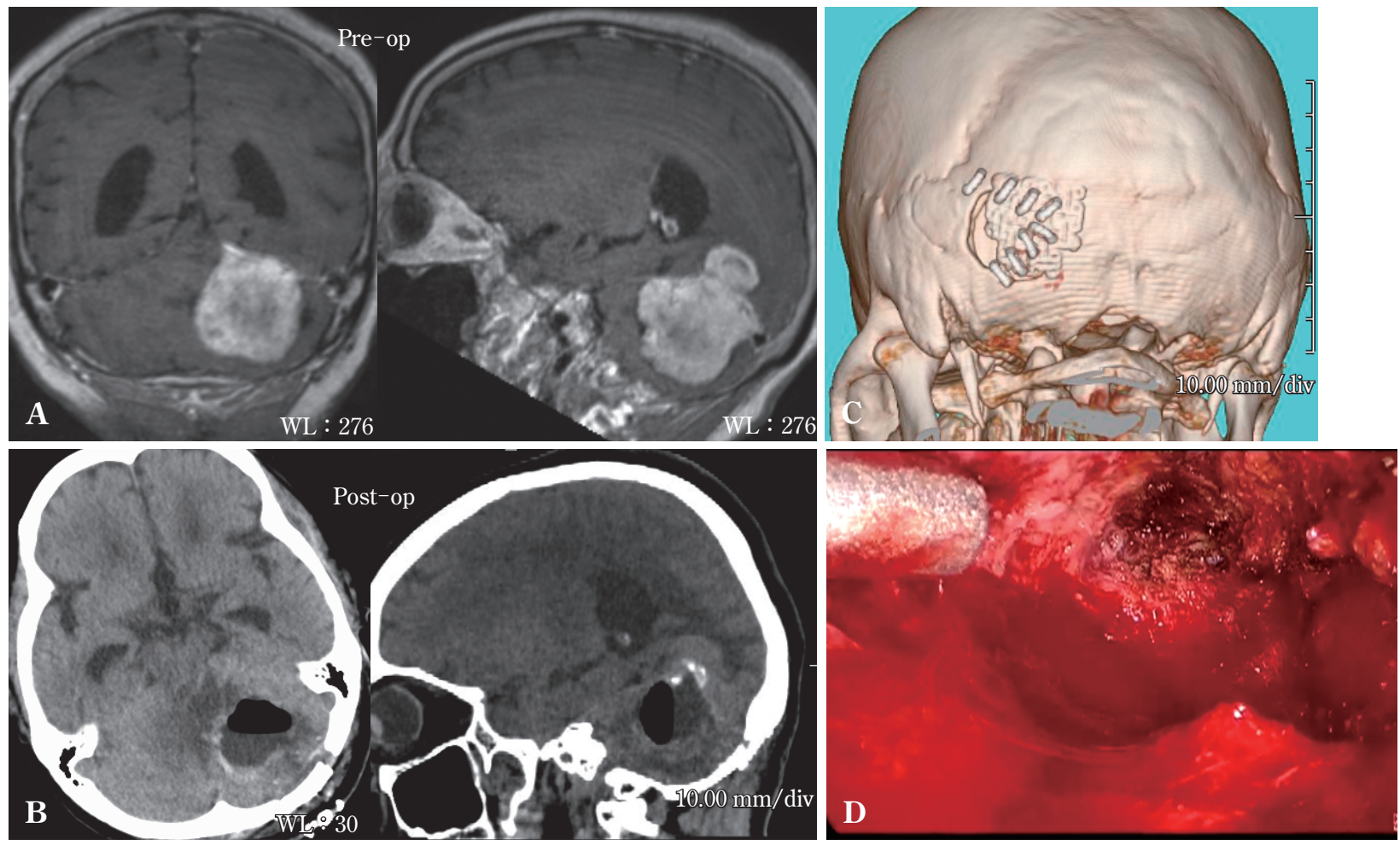

Fig. 9 Representative case of a 79-year-old man with a tentorial meningioma associated with increasing perifocal edema. Minimally invasive endoscopic decompression of the tumor was performed in this patient with a diagnosis of mild dementia.

A : Contrast-enhanced MRI scan (coronal and sagittal views).

B : Postoperative CT scan (day 1, axial and sagittal views) showing sufficient decompression of the tumor and no air in the skull.

C : Postoperative 3D CT scan showing an L-shaped skin incision and a left suboccipital craniotomy $(3 \mathrm{~cm})$.

D : Intraoperative endoscopic view showing near-complete internal decompression.

3D CT : three-dimensional computed tomography

頭蓋内で安全に内視鏡を扱うにはある程度の経験が必要 になる．また，術者 1 人だけではやや煩雑な手技となる. この点は欠点ともいえるが，2 人で協力して手術を進め るこの方法は，手術経験を共有し，術者を育てるという 観点からは長所ともいえる。 また, 現時点では外視鏡, スコープホルダー, 複数のモニターなどは発展途上にあ り，まだ機器や手術システムの改良の余地があり，術式 が完成しているとはいえない.

多視点手術は経鼻手術と眼窩上アプローチの合同手術 のみならず，内視鏡の特徴を利用して，1つの病変に 2 つの方向から観察処置する手術を可能にする。シリン ダー手術と小開頭頭蓋底手術との合同手術，2つのシリ ンダー手術なども実現可能である。 また, 手術の戦略と して, 栄養血管処理のためと, 腫瘍摘出のための異なる アプローチを同時に行うことも内視鏡手術においては可 能となる.

これまでのわれわれの経験から，外視鏡，および内視
鏡を適宜使い分ける手術が合理的であり，実用的である と考えている。しかし，外視鏡は顕微鏡に比べると強拡 大の機能が不十分な機種もある，困難な良性腫瘍の手術 は，操作の慣れた顕微鏡で主要な操作を行い，必要時に は内視鏡を用いる方法も現在においては適切かもしれな い. より性能の高い，小さな外視鏡や，2つのアームを もった高性能な内視鏡ホルダーなど，この術式にあった 機種の開発，発展が課題である．現在まだこの手術ス夕 イルは発展途上であり, 機器の開発も過渡期であるが, 近い将来内視鏡のメリットが十分生かせるシステム, 器 具の成熟が完成する日に期待したい.

\section{結 語}

良性脳腫瘍に対する内視鏡，外視鏡を使った小開頭手 術は, 限られた入り口から, 深部や構造物の影の観察が できる点で優れていた。死角をなくすこと, 多視点手術 
により，より根治性，安全性が高まる。また，高龄髄膜 腫の患者にとつて, よりよい治療は何かを考え, 症状を 緩和し, 腫瘍と共存する選択肢を検討する際に, 内視鏡 のもつ低侵襲性が生かされる。将来の良性脳腫瘍手術に おける根治性，安全性，低侵襲性において内視鏡の果た す役割は大きいと考えられる。

\section{文 献}

1) Ishikawa $T$, Watanabe $T$, Seki $Y$ : How I do it : endoscopic supracerebellar infratentorial approach for torcular meningioma removal. Acta Neurochirurgica（Wien） 161: 16691673,2019 .

2) Jho HD, Alfieri A: Endoscopic glabellar approach to the anterior skull base: a technical note. Minim Invasive Neurosurg 45:185-188, 2002.

3) Kabil MS, Shahinian HK: Application of the supraorbital endoscopic approach to tumors of the anterior cranial base. $J$ Craniofac Surg 16: 1070-1074, 2005.

4) Kabil MS, Shahinian HK : The endoscopic supraorbital approach to tumors of the middle cranial base. Surg Neurol 66: 396-401, 2006.

5) Nagata Y, Watanabe T, Nagatani T, Takeuchi K, Chu J, Wakabayashi $\mathrm{T}$ : The multiscope technique for microvascular decompression. World Neurosurg 103: 310-314, 2017.
6) Nagata Y, Watanabe T, Nagatani T, Takeuchi K, Chu J, Wakabayashi $\mathrm{T}$ : Fully endoscopic combined transsphenoidal and supraorbital keyhole approach for parasellar lesions. $J$ Neurosurg 128: 685-694, 2018.

7) Patil CG, Veeravagu A, Lad SP, Boakye M : Craniotomy for resection of meningioma in the elderly: A multicentre, prospective analysis from the national surgical quality improvement program. J Neurol Neurosurg Psychiatry 81:502$505,2010$.

8) Schwartz TH, Morgenstern PF, Anand VK : Lessons learned in the evolution of endoscopic skull base surgery. $J$ Neurosurg 130:337-346, 2019.

9) Teo C: Application of endoscopy to the surgical management of craniopharyngiomas. Childs Nerv Syst 21:696-700, 2005.

10) Watanabe T, Ito $\mathrm{E}$, Sato $\mathrm{T}$, Ichikawa $\mathrm{M}$, Oda $\mathrm{K}$, Ando H, Matsumoto Y, Sakuma J, Saito K : Combined microsurgical and endoscopic removal of extensive suprasellar and prepontine epidermoid tumors. Neurol Med Chir (Tokyo) 51:684$688,2011$.

11）渡邊 督: 内視鏡による Keyhole transcranial approach の バリエーション. No Shinkei Geka 45:479-491, 2017.

12) Yamaguchi J, Watanabe $T$, Nagatani $T$ : Endoscopic approach via the interhemispheric fissure: the role of an endoscope in a surgical case of multiple falcine lesions. Acta Neurochir (Wien) 159: 1243-1246, 2017.

\section{良性脳腫瘍に対する神経内視鏡手術一今後の方向性一}

\section{渡邊 督 岩味健一郎 岸田 悠吾 永谷 哲也}

神経内視鏡手術の利点は, 最小限の手術外傷で, 最大限の視野が得られる点である. この特徵を生 かし, 良性脳腫瘍に対する内視鏡下小開頭アプローチに取り組んでいる. 画質の向上, 3D 外視鏡の登 場により視点の選択肢が増え，内視鏡亡外視鏡の適宜切り替えが可能となった. また, 経鼻開頭同時 手術のような多視点手術にも内視鏡の利点を生かせる. 低侵襲性に加え, 広い視野角や多視点による 根治性が重要である. 一方, 高齢化社会において症状を緩和する腫瘍外科治療が求められる. 栄養血 管の処理, 減圧術など, 内視鏡手術の利点を生かし活用できる. 根治性, 緩和治療としての低侵襲性, いすれれにおいても神経内視鏡が果たすべき役割は大きい. 